\title{
Protective effect of soursop (Annona muricata linn.) juice on oxidative stress in heat stressed rabbits
}

\author{
Olatunji Abubakar Jimoh ${ }^{1 *}$, Eyanlola Soladoye Ayedun', Waheed Abimbola Oyelade², \\ Olugbenga David Oloruntola ${ }^{3}$, Olajumoke Temidayo Daramola ${ }^{1}$, Simeon Olugbemiga Ayodele ${ }^{1}$ \\ and Idowu Samuel Omoniyi ${ }^{1}$
}

\begin{abstract}
Background: Preventing oxidative stress in heat stressed animals may be possible by increasing antioxidant defence via exogenous administration of antioxidant substrate and/or its precursors. The study aimed to investigate the effect of Soursop juice in mitigating oxidative stress induced by heat stress in rabbit.

Methods: Sixty mixed breed rabbit bucks aged 12-18 months old with the average weight of $1826 \pm 8.35 \mathrm{~g} /$ rabbit, randomly allotted to experimental treatments of four replicates each, in a completely randomized design during high-temperature humidity index in Ado Ekiti, Southwest Nigeria. Soursop juice (SSJ) was administered via oral drenched daily per kg body weight (BW), to designated treatment 1 to $5 ; 0.55 \mathrm{mlkg}^{-1} \mathrm{BW}$ distilled water (control), 0.55 mlkg ${ }^{-1}$ BW SSJ, $1.11 \mathrm{mlkg}^{-1}$ BW SSJ, $1.67 \mathrm{mlkg}^{-1}$ BW SSJ and $2.22 \mathrm{mlkg}^{-1}$ BW SSJ, respectively. Fastened blood samples were collected at days 28 and 56, and assay for serum protein, cholesterol, triglycerides, superoxide dismutase, catalase, reduced glutathione and lipid peroxidation using standard procedures.

Result: Result revealed that SSJ demonstrated hypocholesterolemic effect in a dose-dependent manner throughout the study. Effect of chronic administration of SSJ to heat stressed rabbits proved beneficial, as SSJ reduced serum lipid peroxidation and enhanced antioxidant activity over 8 weeks.
\end{abstract}

Conclusion: Administration of soursop juice to heat-stressed bucks at $2.22 \mathrm{mlkg}^{-1} \mathrm{BW}$ offered optimum antioxidant defense against oxidative stress.

Keywords: Antioxidants, Glutathione, Heat stress, Lipid peroxide, Rabbit, Soursop

\section{Background}

Heat stress is one of the most important stressors especially in hot regions of the world. Effects of heat stress on rabbits bucks has been widely documented to include reduced productivity, compromised the immune system, collapse inefficient thermoregulatory mechanism and reduce fertility when environmental variables induce heat stress [1]. Most recently, exotic breeds of rabbit were introduced to Nigeria, to improve rabbit population in the region. It was observed that oxidative stress greatly compromised animal physiology, with high reactive oxygen

\footnotetext{
* Correspondence: abubakarjimoh2011@gmail.com

${ }^{1}$ Department of Agricultural Technology, Federal Polytechnic Ado Ekiti, Ado Ekiti, Ekiti State, Nigeria

Full list of author information is available at the end of the article
}

species and its metabolites (ROS-M) accumulation in blood and seminal fluid of bucks during heat stress [2]. The accumulations of ROS-M in the biological system is a resultant of decline in antioxidant defense system, notably enzymatic antioxidants and total antioxidant activity. The endogenous production of antioxidant enzymes and the total antioxidant activity of rabbit bucks decline in huge proportion when animals experience heat stress compared to when the environmental variables depict the absence of heat stress [3].

Jimoh et al., [2] reported that mitigating strategies to ameliorate the adverse effects of heat stress in rabbits are imperative for productivity. The possibility of increasing antioxidant defence through exogenous administration of antioxidant substrate and/or its precursors requires

(C) The Author(s). 2018 Open Access This article is distributed under the terms of the Creative Commons Attribution 4.0 International License (http://creativecommons.org/licenses/by/4.0/), which permits unrestricted use, distribution, and 
investigation. Soursop (Annona muricata.L.) belongs to the family Annonaceae which is found throughout the tropics. Several studies have described the medicinal purposes of Annona muricata fruit, leaf, bark, and seed; sedative, antispasmodic, hypoglycemic, hypotensive, smooth muscles relaxant and nervine, cytotoxic against cancer cells. Soursop possess protective and beneficial effect against oxidative stress in rats by decreasing lipid peroxidation and enhancing endogenous antioxidants [4]. These prove as a potential candidate to mitigate oxidative stress induced by heat stress in the rabbit in the tropics. This study investigates the protective effect of soursop juice against heat stress-induced oxidative stress in rabbit bucks.

\section{Methods}

The study was conducted at the rabbit unit of Teaching and Research Farm, Department of Agricultural Technology, Federal Polytechnic, Ado-Ekiti, Nigeria. The study area is located between latitude $7^{\circ} 3^{\prime} 7^{\prime \prime} \mathrm{N} 7^{\prime} 12^{\prime \prime} \mathrm{N}$ and latitude $5^{\circ} 11^{\prime \prime} \mathrm{E}$ and $5^{\circ} 31^{\prime \prime} \mathrm{E}$. The temperature-humidity index (THI), an indicator of thermal comfort level for animals in an enclosure was calculated as modified by Marai et al. [5] and given as:

$$
\mathrm{THI}=\mathrm{t}-[(0.31-0.31 \times \mathrm{RH} \mathrm{t}-14.4)
$$

Where $\mathrm{RH}=$ relative humidity $\quad / 100 . \quad \mathrm{t}=\mathrm{ambient}$ temperature.

The values of THI obtained for rabbit are classified as:

$<27.8{ }^{\circ} \mathrm{C}=$ absence of heat stress,

$27.8-28.9^{\circ} \mathrm{C}=$ moderate heat stress,

$28.9-30{ }^{\circ} \mathrm{C}=$ severe heat stress and.

above $30{ }^{\circ} \mathrm{C}=$ very severe heat stress (Marai et al.,) [5].

The study was conducted between December 2017 and January 2018 with average daily THI of $29.94 \pm 1.56$ and $28.59 \pm 3.10$ at the rabbit unit, which is the peak of the dry season in the study area at the time.

\section{Collection and extraction of soursop juice}

Ripe soursop (Annona muricata) fruit was harvested fresh and it was extracted in the Teaching and Research Farm of the Agricultural Technology, Federal Polytechnic Ado -Ekiti, Nigeria. The fruits were peeled, weighed and the fruit pulp blended (without the seeds) with the ratio of 1:2 (pulp: distilled water). The soursop juice was clarified with juice extractor (Mikachi model No 1706). The juice obtained was designated as soursop juice (SSJ) and kept frozen $4{ }^{\circ} \mathrm{C}$ in disposable $5 \mathrm{ml}$ sterile sample bottles until its required for use.

\section{Experimental animal and management}

Sixty (60) mixed breed (New Zealand white x Chinchilla) male rabbit bucks kept in a battery cage system kept in an open-sided house were used for the experiment. The rabbit house has natural lighting program (12D:12 L), with the dynamic ventilation system. The experimental units are made of wire mesh double sided boxes of 1.1sq.m. The animals were fed ad libitum with diets containing crude protein $17.05 \%$, digestible energy $2592.06 \mathrm{Kcal} / \mathrm{kg}$, crude fibre $10.02 \%$, calcium $0.45 \%$ and phosphorus $0.21 \%$ as shown in Table 1 . Freshwater was made available to the animals always. Other routines and periodic management practices necessary for rabbit production were carried out.

The bucks were adult of 12-18 months old with the average weight of $1826 \pm 8.35$ g. 60 bucks were randomly allotted to five experimental treatments of four replicates (3 bucks per replicate) per treatment in a completely randomised design. SSJ was administered per $\mathrm{kg}$ body weight (BW), designated as treatment 1 to 5 , administered $0.55 \mathrm{mlkg}^{-1} \mathrm{BW}$ distilled water (control), $0.55 \mathrm{mlkg}^{-1} \mathrm{BW}$ SSJ, $1.11 \mathrm{mlkg}^{-1} \mathrm{BW}$ SSJ, $1.67 \mathrm{mlkg}^{-1} \mathrm{BW}$ SSJ and 2.22 mlkg ${ }^{-1}$ BW SSJ respectively. Each treatment consists of 12 bucks. The soursop juice was administered orally to the rabbit in the morning between 8:00 am and 8:30 am daily to all bucks in a study that lasted for eight weeks.

\section{Sample collection and analysis}

A baseline blood sample was collected from all rabbits at least temperature humidity index, to serve as positive

Table 1 Gross composition of experimental diet

\begin{tabular}{ll}
\hline Ingredient & Inclusion (g/100 g) \\
\hline Maize & 25 \\
Wheat offal & 5 \\
Rice bran & 6 \\
BDG & 5 \\
SBM & 17 \\
Groundnut haulms & 40 \\
Methionine & 0.4 \\
Lysine & 0.1 \\
Bone meal & 1 \\
Premix & 0.25 \\
Salt & 0.25 \\
Total & 100 \\
Calculated nutrient composition & \\
Dry matter (\%) & 87.87 \\
Crude protein (\%) & 16.44 \\
Digestible energy (kcal/kg) & 2717.86 \\
Ether extract (\%) & 3.34 \\
Crude fibre (\%) & 16.48 \\
Lysine (\%) & 1.01 \\
Methionine (\%) & 0.75 \\
Calcium (\%) & 1.60 \\
Phosphorus (\%) & 0.45 \\
\hline
\end{tabular}


control as non-heat stressed treatment. The fastened blood sample was collected at 28 days and 56 days of the study. Blood was collected through the marginal ear vein into a sample bottle. Serum was separated by centrifugation (Medi Scan centrifuge model No 800D) and stored at $-2{ }^{\circ} \mathrm{C}$ before analysis. Serum obtained was assayed for total protein, albumin, cholesterol, and triglyceride using commercial assay kits and its procedure, lipid peroxidation, reduced glutathione, catalase, and superoxide dismutase activity using standard procedures.

Superoxide dismutase (SOD); to $2.1 \mathrm{ml}$ of $50 \mathrm{~m} \mathrm{M}$ butter, $0.02 \mathrm{ml}$ of enzyme source and $0.86 \mathrm{ml}$ of distilled water. The reaction is initiated with $0.02 \mathrm{ml}$ of $10 \mathrm{mM}$ pyrogallol and change in absorbance monitored at $420 \mathrm{~mm}$. One unit of SOD is defined as that amount of enzyme required to inhibit to auto-oxidation of pyrogallol by $50 \%$ in standard assay system of $3 \mathrm{ml}$. The specific activity is expressed as unit $/ \mathrm{min} / \mathrm{mg}$ protein.

Catalase activity; the assay system contain $1.9 \mathrm{ml}, 0.05 \mathrm{M}$ buffer $\mathrm{PH} 7.0$ and $1.0 \mathrm{ml} 0.059 \mathrm{M}$ water. The reaction is initiated by addition of $0.1 \mathrm{ml}$ enzyme source. The decrease in absorbance is monitored at 1 min interval for $5 \mathrm{~min}$ at $240 \mathrm{~min}$ and activity is expressed as moles of water decomposed $/ \mathrm{min} / \mathrm{mg}$ protein.

The assay for lipid peroxidation; The reaction mixture in a total volume of $3.0 \mathrm{ml}$ contained $1.0 \mathrm{ml}$ serum, $1.0 \mathrm{ml}$ of TCA $(0.67 \%)$. All the test tubes were placed in a boiling water bath for a period of $45 \mathrm{~min}$. The tubes were shifted to the ice bath and then centrifuged at $2500 \mathrm{rpm}$ for $10 \mathrm{~min}$. The amount of malondialdehyde (MDA) formed in each of the samples was assessed by measuring the optical density of the supernatant at $532 \mathrm{~nm}$.

The glutathione (GSH) content; in which $1.0 \mathrm{ml}$ of PMS fraction (10\%) was mixed with $1.0 \mathrm{ml}$ of sulphosalicylic acid (4\%). The sample was incubated at $4{ }^{\circ} \mathrm{C}$ for at least $1 \mathrm{~h}$ and then subjected to centrifugation at $1200 \mathrm{rpm}$ for $15 \mathrm{~min}$ at $4{ }^{\circ} \mathrm{C}$. The assay mixture contained $0.4 \mathrm{ml}$ filtered aliquot, $2.2 \mathrm{ml}$ phosphate, buffer $(0.1 \mathrm{M}, \mathrm{PH} 7.4)$ and $0.4 \mathrm{ml}$ DTNB $(10 \mathrm{mM})$ in a total volume of $3.0 \mathrm{ml}$. The yellow colour developed was read immediately at $412 \mathrm{~mm}$.

\section{Statistical analysis}

Data obtained were subjected to analysis of variance at $\alpha=0.05$, the general linear model procedure of SAS, while means were separated using Duncan's multiple range test of same software.

The statistical model is as the following:

$$
\mathrm{Y}_{i j l}=\mu+\mathrm{B}_{i}+\mathrm{e}_{i j l}
$$

Where $Y_{i j l}$ represents the value of serum biochemical parameters and oxidative status measured in the $t^{\text {th }}$ animal; $\mu$ is the overall mean for each character; $\mathrm{B}_{i}$ is the fixed effect of $i^{\text {th }}$ Soursop (SSJ) was administered 5 levels $\left(i=0.55 \mathrm{mlkg}^{-1} \mathrm{BW}\right.$ water (control), $0.55 \mathrm{mlkg}^{-1} \mathrm{BW}$ SSJ, $1.11 \mathrm{mlkg}^{-1} \mathrm{BW}$ SSJ, $1.67 \mathrm{mlkg}^{-1} \mathrm{BW} \mathrm{SSJ}$ and $2.22 \mathrm{mlkg}^{-1} \mathrm{BW} \mathrm{SSJ);} \mathrm{and}$ $\mathrm{e}_{i j l}$ is the random residual effect.

\section{Results}

Serum oxidative status of non-heat stressed treatment is shown in Table 2. Total protein, antioxidant activities were higher than values obtained in heat stressed groups. However, cholesterol and lipid peroxidation were lower in non-heat stressed group compared with heat stressed groups.

\section{Serum oxidative status of heat-stressed bucks gavaged with soursop juice}

Serum oxidative status of heat stressed bucks gavaged with soursop juice for 4 weeks is shown in Table 3. The serum total protein of bucks on control were statistically $(p>0.05)$ similar with bucks on treatments 3,4 and 5 . Cholesterol of bucks on SSJ based treatments were significantly $(p<0.05)$ lower than those on treatment 1. Triglyceride declined with increased SSJ administration. Bucks on treatments 2, 3, 4 and 5 had significantly $(p<0.05)$ low values while bucks not offered SSJ had the statistically highest value. Serum lipid peroxidation was significantly $(p<0.05)$ highest in the buck on control and least in bucks offered treatments 4 and 5 . However, bucks on treatments 2 and 3 had statistically $(p>0.05)$ similar lipid peroxidation values and were significantly $(\mathrm{p}<0.05)$ higher than bucks on treatments 4 and 5. Glutathione of bucks on treatments 4 and 5 was significantly $(p<0.05)$ highest across the treatments with significantly least values obtained in bucks on treatments 1 and 2 . Superoxide dismutase activity was highest statistically in bucks on treatment 5 , with bucks on treatments 1 and 2 having the significantly $(\mathrm{p}<0.05)$ least values. Bucks on treatment 3 and 4 had lower SOD than bucks on treatment 5. Serum catalase activity in SSJ based groups was significantly higher than the control.

Table 2 baseline of serum oxidative status of the experimental rabbits at absence of heat stress

\begin{tabular}{ll}
\hline Parameters & $\begin{array}{l}\text { Baseline assessment } \\
\text { (un-heat stressed treatment) }\end{array}$ \\
\hline Total Protein $(\mathrm{g} / \mathrm{dL})$ & 54.8 \\
Cholesterol $(\mathrm{mg} / \mathrm{dL})$ & 51.04 \\
Triglyceride $(\mathrm{mg} / \mathrm{dL})$ & 114.53 \\
Lipid Peroxidation $(\mathrm{TBARS} / \mathrm{mg}$ protein) & 0.09 \\
Glutathione $(\mu \mathrm{g} \mathrm{GSH} / \mathrm{min} / \mathrm{mg}$ protein) & 54.05 \\
Catalase (nm $\mathrm{H}_{2} \mathrm{O}_{2} / \mathrm{min} / \mathrm{mg}$ protein) & 132.77 \\
Superoxide Dismutase $(\mathrm{U} / \mathrm{min} / \mathrm{mg}$ protein) & 78.68 \\
\hline
\end{tabular}


Table 3 Serum oxidative status of heat stressed bucks gavaged with soursop juice for 4 weeks

\begin{tabular}{|c|c|c|c|c|c|c|c|}
\hline & & $\begin{array}{l}\text { Treatment } 1 \\
\left(0 \mathrm{mlkg}^{-1} \mathrm{BW}\right)\end{array}$ & $\begin{array}{l}\text { Treatment } 2 \\
\left(0.55 \mathrm{mlkg}^{-1} \mathrm{BW}\right)\end{array}$ & $\begin{array}{l}\text { Treatment } 3 \\
\left(1.11 \mathrm{mlkg}^{-1} \mathrm{BW}\right)\end{array}$ & $\begin{array}{l}\text { Treatment } 4 \\
\left(1.67 \mathrm{~m}^{-1} \mathrm{~kg}^{-1} \mathrm{BW}\right)\end{array}$ & $\begin{array}{l}\text { Treatment } 5 \\
\left(2.22 \mathrm{~m}^{-1} \mathrm{~kg}^{-1} \mathrm{BW}\right)\end{array}$ & SEM \\
\hline Total Protein (g/dL) & 54.8 & $14.92^{\mathrm{a}}$ & $8.57^{\mathrm{b}}$ & $14.28^{\mathrm{a}}$ & $13.18^{\mathrm{a}}$ & $11.10^{\mathrm{a}}$ & 1.24 \\
\hline Cholesterol (mg/dL) & 51.04 & $61.17^{\mathrm{a}}$ & $48.26^{b}$ & $46.95^{b}$ & $50.47^{b}$ & $50.88^{b}$ & 3.86 \\
\hline Triglyceride (mg/dL) & 114.53 & $148.01^{\mathrm{a}}$ & $129.61^{b}$ & $103.49^{c}$ & $103.31^{c}$ & $99.52^{c}$ & 9.09 \\
\hline $\begin{array}{l}\text { Lipid Peroxidation } \\
\text { (TBARS/mg protein) }\end{array}$ & 0.09 & $1.46^{\mathrm{a}}$ & $0.90^{b}$ & $0.96^{b}$ & $0.79^{c}$ & $0.75^{c}$ & 0.05 \\
\hline $\begin{array}{l}\text { Glutathione } \\
\text { ( } \mathrm{g} \text { GSH /min/mg protein) }\end{array}$ & 54.05 & $17.39^{c}$ & $20.90^{c}$ & $27.08^{b}$ & $33.86^{\mathrm{a}}$ & $38.46^{\mathrm{a}}$ & 3.48 \\
\hline $\begin{array}{l}\text { Catalase } \\
\text { (nm H} \mathrm{O}_{2} / \mathrm{min} / \mathrm{mg} \text { protein) }\end{array}$ & 132.77 & $54.01^{b}$ & $95.05^{a}$ & $87.38^{a}$ & $90.02^{a}$ & $96.50^{\mathrm{a}}$ & 6.38 \\
\hline $\begin{array}{l}\text { Superoxide Dismutase } \\
\text { (U/min/mg protein) }\end{array}$ & 78.68 & $21.74^{c}$ & $24.64^{c}$ & $35.87^{b}$ & $38.26^{b}$ & $60.63^{a}$ & 3.62 \\
\hline
\end{tabular}

Different superscipt denote statistically significant differences at $p \leq 0.05$

Serum oxidative status of heat stressed bucks gavaged with soursop juice for 8 weeks (Table 4) reveal that serum total protein in bucks on treatments 3,4 and 5 are statistically similar and significantly $(p<0.05)$ lower than bucks on treatments 1 and 2. Serum cholesterol of bucks on treatments 1,2 and 3 are similar and were statistically $(p<0.05)$ higher than bucks on treatment 4 and 5 . Triglyceride of bucks on control was significantly $(p<0.05)$ higher than bucks on SSJ based treatments. Serum lipid peroxidation of bucks on treatment 1 was significantly $(\mathrm{p}<0.05)$ highest, while bucks on treatment 5 had significantly $(p<0.05)$ least values. Serum glutathione activity of bucks on SSJ treatments were statistically similar and significantly $(\mathrm{p}<0.05)$ higher than bucks on control. Serum catalase activity in SSJ based groups was significantly higher than the control. Superoxide dismutase activity of bucks on treatment $1,2,3$ and 4 was statistically similar and significantly $(\mathrm{p}<0.05)$ lower than SOD of buck on treatment 5 .

\section{Discussion}

Cholesterol and triglyceride values of SSJ drenched bucks were lower than the control over 8 weeks. This shows that SSJ demonstrated the hypocholesterolemic effect in a dose-dependent manner throughout the study, as evident in cholesterol and triglyceride values. This corroborates reports that $A$. muricata lowers hypertriglyceridemia and hypercholesterolemia in alloxan-induced diabetic rats [6]. Zheng et al. [7] demonstrated that fruit and vegetable juice reduce total cholesterol in the body and improve cholesterol profile in the blood. The improving blood lipids effects of the juice blend were attributed to the high content of total polyphenol. The trend of result shows that total protein of SSJ drenched bucks was lower than control and increase across the treatments with the period of administration.

SSJ reduced serum lipid peroxidation throughout the study, this proves a beneficial effect of chronic administration of SSJ on heat stressed bucks. This is revealed by values of lipid peroxidation in SSJ drenched bucks,

Table 4 Serum oxidative status of heat stressed bucks gavaged with soursop juice for 8 weeks

\begin{tabular}{|c|c|c|c|c|c|c|c|}
\hline & $\begin{array}{l}\text { Baseline assessment } \\
\text { (un-heat stressed } \\
\text { treatment) }\end{array}$ & $\begin{array}{l}\text { Treatment } 1 \\
\left(0 \mathrm{mlkg}^{-1} \mathrm{BW}\right)\end{array}$ & $\begin{array}{l}\text { Treatment } 2 \\
\left(0.55 \mathrm{mlkg}^{-1} \mathrm{BW}\right)\end{array}$ & $\begin{array}{l}\text { Treatment } 3 \\
\left(1.11 \mathrm{mlkg}^{-1} \mathrm{BW}\right)\end{array}$ & $\begin{array}{l}\text { Treatment } 4 \\
\left(1.67 \mathrm{mlkg}^{-1} \mathrm{BW}\right)\end{array}$ & $\begin{array}{l}\text { Treatment } 5 \\
\left(2.22 \mathrm{mlkg}^{-1} \mathrm{BW}\right)\end{array}$ & SEM \\
\hline Total Protein (g/dL) & 54.8 & $43.39^{a}$ & $39.20^{a}$ & $32.70^{b}$ & $29.60^{b}$ & $24.15^{b}$ & 2.27 \\
\hline Cholesterol (mg/dL) & 51.04 & $57.91^{a}$ & $50.19^{a}$ & $51.91^{\mathrm{a}}$ & $41.03^{b}$ & $36.68^{b}$ & 2.97 \\
\hline Triglyceride (mg/dL) & 114.53 & $214.78^{\mathrm{a}}$ & $134.15^{b}$ & $177.05^{\mathrm{b}}$ & $155.75^{\mathrm{b}}$ & $129.77^{b}$ & 10.89 \\
\hline $\begin{array}{l}\text { Lipid Peroxidation } \\
\text { (TBARS/mg protein) }\end{array}$ & 0.09 & $1.41^{\mathrm{a}}$ & $0.35^{\mathrm{b}}$ & $0.38^{b}$ & $0.29^{b}$ & $0.19^{c}$ & 0.04 \\
\hline $\begin{array}{l}\text { Glutathione }(\mu \mathrm{g} \mathrm{GSH} \\
/ \mathrm{min} / \mathrm{mg} \text { protein) }\end{array}$ & 54.05 & $27.79^{b}$ & $37.28^{\mathrm{a}}$ & $38.01^{a}$ & $45.31^{\mathrm{a}}$ & $45.99^{\mathrm{a}}$ & 4.29 \\
\hline $\begin{array}{l}\text { Catalase }\left(\mathrm{nm} \mathrm{H}_{2} \mathrm{O}_{2}\right. \\
/ \mathrm{min} / \mathrm{mg} \text { protein) }\end{array}$ & 132.77 & $43.58^{b}$ & $102.42^{\mathrm{a}}$ & $100.89^{a}$ & $103.36^{\mathrm{a}}$ & $109.03^{\mathrm{a}}$ & 7.29 \\
\hline $\begin{array}{l}\text { Superoxide Dismutase } \\
\text { (U/min/mg protein) }\end{array}$ & 78.68 & $17.39^{b}$ & $20.29^{b}$ & $19.57^{b}$ & $21.74^{b}$ & $28.70^{a}$ & 3.01 \\
\hline
\end{tabular}

Different superscipt denote statistically significant differences at $p \leq 0.05$ 
which were lower at 8 weeks than at 4 weeks of the study. This reveals that the duration of administration of SSJ enhanced mitigation of oxidant accumulations and/ or production in heat stressed bucks. Hypercholesterolemia is related to increased lipid peroxidation [7], thus the mechanism of soursop juice reduction of cholesterol contributes to lowering lipid peroxidation as revealed in this work. Similarly, cranberry powder has been shown to decrease the accumulation of malondialdehyde (MDA, an indicator of oxidative damage) in male New Zealand rabbit kidneys [8]. This is also supported by claims that $A$. muricata extract has a protective and beneficial effect on hepatic tissues subjected to STZinduced oxidative stress, by decreasing lipid peroxidation and indirectly enhancing production of insulin and endogenous antioxidants [4].

Glutathione activity in heat stressed bucks increased with the dosage of SSJ administration at 4 weeks. However, at 8 weeks though values were higher than at 4 weeks, the effect of the accumulation of production of glutathione could account for their similar values in SSJ drenched groups. The least values of glutathione were obtained in control group throughout the study, this demonstrates the enhancement of glutathione activity in heat stressed bucks by SSJ to counteract the accumulation of hydrogen peroxide. This is also observed in catalase activity of the bucks, catalase and glutathione are responsible for the elimination of hydrogen peroxide in biological systems. Similarly, ginger also a natural antioxidant spice has been reported to decrease lipid peroxidation, increasing GSH content and maintaining normal levels of antioxidant enzymes in rats [9]. Effect of chronic antioxidant-rich fruit administration was also reported by Kota et al. [10] in rat supplemented ginger for one month, which recorded significant increases in activity of antioxidant enzymes (superoxide dismutase, glutathione peroxidase, and catalase) in the liver. Superoxide dismutase activity was higher at 4 weeks in SSJ drenched bucks than at 8 weeks. This could be due to the first line defense of SOD to convert superoxide anion to hydrogen peroxide in heat stressed bucks at 4 weeks. After regulating superoxide anion production and elimination, SOD activity declines to favour catalase and glutathione activity at the latter stage, to counteract the hydrogen peroxide being produced as a metabolite of SOD. It suggests that SOD functions in tandem with catalase and glutathione regulate superoxide anion and hydrogen peroxide productions and/or accumulation in the bucks. This result in mitigating oxidants (lipid peroxides) and prevent oxidative stress in heat stressed bucks. This demonstrates SSJ mechanism to mitigate oxidative stress in heat stressed bucks. Contrariwise, cranberry and ginger had no effect on the oxidative stress or antioxidant status in exercising horses
[11]. This study also agrees with the notion that antioxidant-rich juice/extracts are more effective when the body has undergone intense, long-term oxidative stress, rather than in healthy individuals or in individuals undergoing short-term or acute oxidative stress [11]. Zheng et al. [7] review antioxidant effects of several fruits and vegetable juice and concluded that the consumption of juice enhanced total antioxidant activity and enzymatic antioxidants and are important therapies to ameliorate oxidative stress and its related diseases. Similarly, Syahida et al. [12] reported that Annona muricata L. extract contains the high total antioxidant, which improved the total antioxidant status of Sprague-Dawley rats as the dosage increased, which is good in promoting health.

\section{Conclusion}

This study reveals that chronic oral administration of soursop juice proved beneficial in promoting good health of heat-stressed bucks. Soursop juice reduced serum lipid peroxidation and enhanced antioxidant activity in heat stressed rabbit over 8 weeks. Administration of soursop juice to heat-stressed bucks at 2.22 $\mathrm{mlkg}^{-1} \mathrm{BW}$ offered optimum antioxidant defense against oxidative stress.

\section{Abbreviations}

BW: Body weight; GSH: Glutathione; MDA: Malondialdehyde; ROS-M: Reactive oxygen species and its metabolites; SAS: Statistical analysis software; SOD: Superoxide dismutase; SSJ: Soursop juice; THI: Temperaturehumidity index

\section{Acknowledgements \\ The authors appreciate the Teaching and Research Farm, Department of Agricultural Technology, Federal Polytechnic, Ado-Ekiti, Nigeria, for making available animals for the research. We are grateful to Kolawole Khadijah Abidemi and Abiola Saheed Olajide for the care and handling of the animals, and their resourcefulness to the study.}

\section{Funding}

This research did not receive any specific grant from any funding agency in the public, commercial or not-for profit sector.

\section{Availability of data and materials \\ "The study was undertaken with approval from institutional ethics committee for care and use of animal for research of the Federal polytechnic Ado Ekiti."}

\section{Authors' contributions}

JOA designed and supervised the study, carried out statistical analysis and wrote the first manuscript. AES co supervised the study and wrote the experimental layout. ASO and OIS carried out the field work, OWO carried out the laboratory assay, ODO and DOT approved the experimental protocol, read and corrected the first manuscript. All authors read and approve the final manuscript.

\section{Ethical approval}

This research was undertaken with approval from institutional ethics committee of the Department of Agricultural Technology, Federal

Polytechnic, Ado-Ekiti. The institutional and national standards for the care and use of animals for research in the Research Policy Handbook of the Federal Polytechnic, Ado-Ekiti were followed and appropriate measures were taken to minimize pain or discomfort on the animals. 


\section{Competing interests}

The authors declare that there are no competing interests to the publication of this article.

\section{Publisher's Note}

Springer Nature remains neutral with regard to jurisdictional claims in published maps and institutional affiliations.

\section{Author details}

'Department of Agricultural Technology, Federal Polytechnic Ado Ekiti, Ado Ekiti, Ekiti State, Nigeria. ${ }^{2}$ Department of Science Technology, Federal Polytechnic, Ado Ekiti, Ekiti State, Nigeria. ${ }^{3}$ Department of Animal Science, Adekunle Ajasin University Akungba Akoko, Akungba Akoko, Ondo State, Nigeria.

Received: 25 September 2018 Accepted: 2 November 2018

Published online: 16 November 2018

\section{References}

1. Jimoh OA, Ewuola EO. Thermoregulatory response of exotic rabbit breeds during peak temperature humidity index of Ibadan. Tropical Animal Production investigation. 2016;19(1):41-7.

2. Jimoh OA, Ewuola EO, Balogun AS. Oxidative stress markers in exotic breeds of rabbit during peak of heat stress in Ibadan, Nigeria. Journal of Advances in Biology and Biotechnology. 2017;12(1):1-9. https://doi.org/10.9734/JABB/ 2017/30437.

3. Jimoh OA. Assessment of the oxidative stress markers and reproductive performance of four exotic breeds of rabbit in Ibadan. Ph.D. Thesis 2016, University of Ibadan, Ibadan, Nigeria.

4. Adewole SO,Ojewole JAO. Protective effects of Annona muricata linn. (annonaceae) leaf aqueous extract on serum lipid profiles and oxidative stress in hepatocytes of streptozotocin-treated diabetic rats. Afr. J. Traditional, Complementary and Alternative Medicines 2009, 6 (1): 30-41.

5. Marai IFM, Ayyat MS. Abd El-MonemUM. Growth performance and reproductive traits at first parity of New Zealand white female rabbits as affected by heat stress and its alleviation, under Egyptian conditions. Trop Anim Health Prod. 2001:33:1-12.

6. Sawant TP, Gogle DP. A brief review on recent advances in clinical research of Annona muricata. International journal of universal pharmacy and bio. Sciences. 2014;3(3):267-304

7. Zheng J, Zhou Y, Li S, Zhang P, Zhou T, D X, Li H. Review effects and mechanisms of fruit and vegetable juices on cardiovascular diseases. Int J Mol Sci. 2017;18(555):1-15. https://doi.org/10.3390/ijms18030555.

8. Han CH, Kim SH, Kang SH, Shin OR, Lee HK, Kim HJ, Cho YH. Protective effects of cranberries on infected-induced oxidative renal damage in a rabbit model of vesico-ureteric reflux. BJU Int. 2007:100:1172-5.

9. Ahmed RS, Seth V, Pasha ST, Banerjee BD. Influence of dietary ginger (Zingiber Officinale Rosc) on oxidative stress induced by malathion in rats. Food Chem Toxicol. 2000;38:443-50.

10. Kota N, Krishna P, Polasa K. Alterations in antioxidant status of rats following intake of ginger through diet. Food Chem. 2008;106:991-6.

11. Smarsh DN, Liburt N, Streltsova J, Mckeever K, Williams CA. Oxidative stress and antioxidant status in intensely exercising horses administered nutraceutical extracts. Equine Vet J. 2010;42(Suppl. 38):317-22. https://doi. org/10.1111/j.2042-3306.2010.00182.x.

12. Syahida M, Maskat MY, Suri R, Mamot S, Hadijah H. Soursop (Annona muricata L.): blood hematology and serum biochemistry of Sprague-Dawley rats. Int Food Res J. 2012;19(3):955-9.

Ready to submit your research? Choose BMC and benefit from:

- fast, convenient online submission

- thorough peer review by experienced researchers in your field

- rapid publication on acceptance

- support for research data, including large and complex data types

- gold Open Access which fosters wider collaboration and increased citations

- maximum visibility for your research: over $100 \mathrm{M}$ website views per year

At $\mathrm{BMC}$, research is always in progress.

Learn more biomedcentral.com/submissions 